Supplement of Atmos. Chem. Phys., 14, 13175-13188, 2014

http://www.atmos-chem-phys.net/14/13175/2014/

doi:10.5194/acp-14-13175-2014-supplement

(C) Author(s) 2014. CC Attribution 3.0 License.

(c) (i)

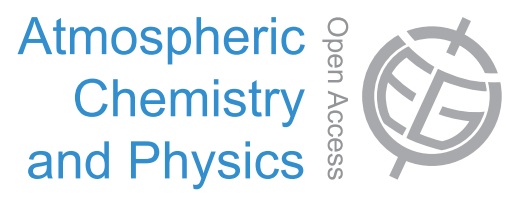

Supplement of

\title{
Ground-level ozone in four Chinese cities: precursors, regional transport and heterogeneous processes
}

\section{K. Xue et al.}

Correspondence to: L. K. Xue (xuelikun@gmail.com) and T. Wang (cetwang@polyu.edu.hk) 
Table S1. The quantified hydrocarbon species and the categorization.

\begin{tabular}{|c|c|c|}
\hline \multicolumn{2}{|c|}{ Category } & Species \\
\hline \multirow{4}{*}{ AHC } & LRHC & methane, ethane, propane, ethyne, benzene \\
\hline & $\mathrm{C} 4 \mathrm{HC}$ & $\begin{array}{l}n \text {-butane, } i \text {-butane, } n \text {-pentane, } i \text {-pentane, } n \text {-hexane, } n \text {-heptane, } n \text {-octane, } \\
n \text {-nonane, } n \text {-decane }{ }^{*}, 2,2 \text {-dimethylbutane, } 2,3 \text {-dimethylbutane, } \\
\text { 2-methylpentane, 3-methylpentane, } 2,2 \text {-dimethylpentane }{ }^{=}, \\
\text {2,3-dimethylpentane }=\text {, 2-methylhexane, } 3 \text {-methylhexane, } \\
\text { 2,2,4-trimethylpentane, 2,3,4-trimethylpentane }{ }^{\#,=, \&}, \text { cyclopentane }^{=, \&}, \\
\text { methylcyclopentane }^{\#, \&}, \text { cyclohexane }{ }^{\&}, \text { methylcyclohexane }{ }^{\#,=, \&}\end{array}$ \\
\hline & Alkenes & $\begin{array}{l}\text { ethene, propene, } 1 \text {-butene, } i \text {-butene, trans-2-butene, } \text { cis-2-butene, } \\
\text { 1,3-butadiene, } 1 \text {-pentene, } \text { trans-2-pentene }{ }^{=}, \text {cis-2-pentene }^{=} \\
\text {3-methyl-1-butene }{ }^{\&}, 2 \text {-methyl-1-butene } \mathrm{e}^{\#,=, \&}, 2 \text {-methyl-2-butene } \mathrm{e}^{\#,=, \&}\end{array}$ \\
\hline & R-AROM & $\begin{array}{l}\text { toluene, ethylbenzene, } m \text {-xylene, } p \text {-xylene, } o \text {-xylene, } n \text {-propylbenzene }{ }^{\&} \text {, } \\
i \text {-propylbenzene }{ }^{\#, \&}, m \text {-ethyltoluene }{ }^{\&}, p \text {-ethyltoluene }{ }^{\&}, o \text {-ethyltoluene }{ }^{\&} \text {, } \\
\text { 1,2,3-trimethylbenzene, } 1,2 \text {-trimethylbenzene, } 1,3,5 \text {-trimethylbenzene, } \\
\text { styrene }^{\#,=, \&}\end{array}$ \\
\hline \multicolumn{2}{|c|}{ BHC } & isoprene, $\alpha$-pinene, $\beta$-pinene ${ }^{\&}$ \\
\hline
\end{tabular}

${ }^{*}$ Species that were not measured in Beijing;

" Species that were not measured in Shanghai;

= Species that were not measured in Guangzhou;

${ }^{\&}$ Species that were not measured in Lanzhou.

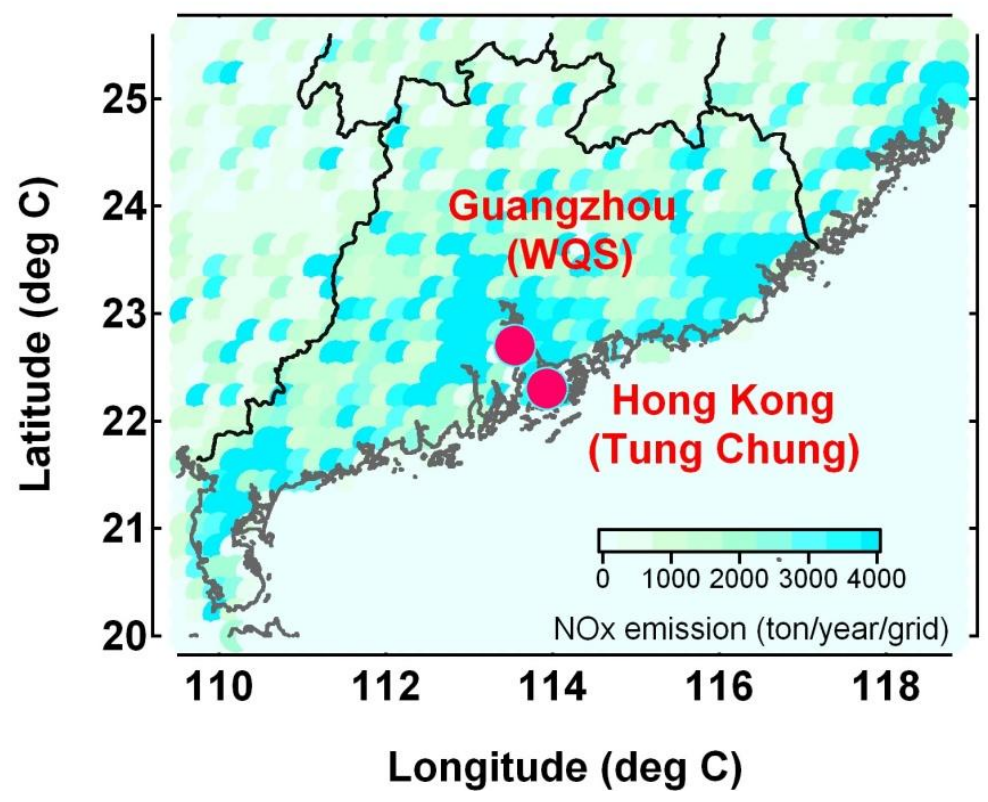

Figure S1. Locations of the Wan Qing Sha (Guangzhou) and Tung Chung (Hong Kong) sites. 


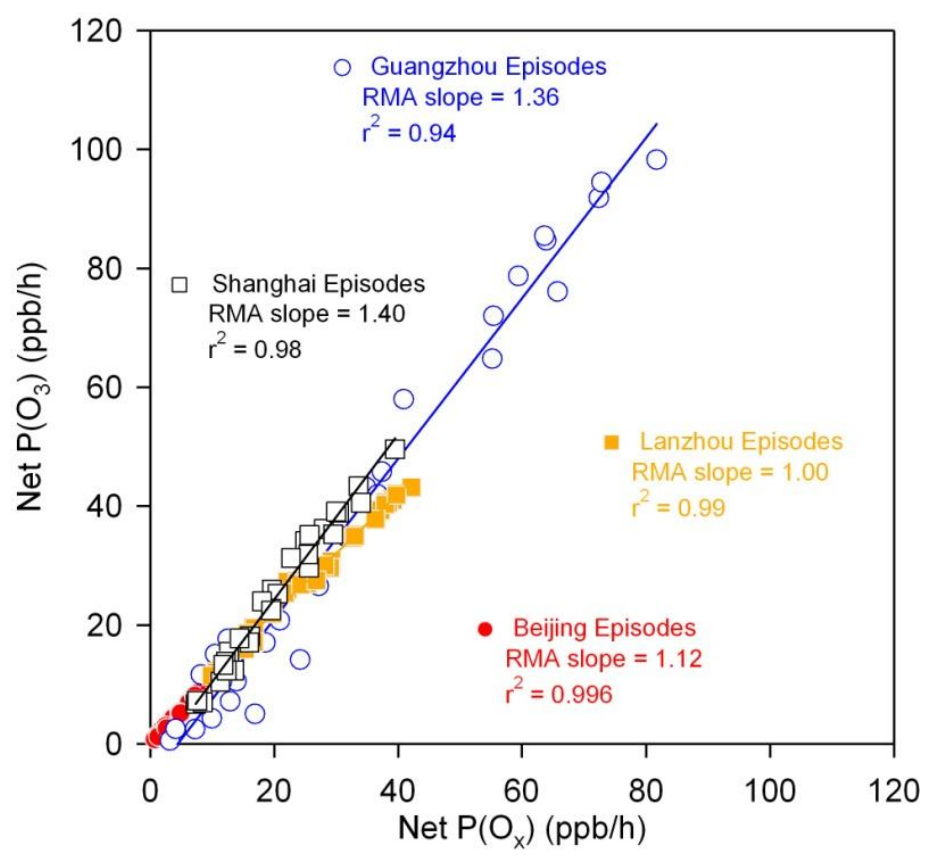

Figure S2. Comparison of the OBM-calculated daytime net production rates of $\mathrm{O}_{3}$ and $\mathrm{O}_{x}$ $\left(=\mathrm{O}_{3}+\mathrm{NO}_{2}\right.$; from traditional method $)$ in the four cities. The net $\mathrm{O}_{3}$ rates are overall systematically higher than those of $\mathrm{O}_{\mathrm{x}}$ because of the net loss (oxidation) of $\mathrm{NO}_{2}$ at daytime. The larger slopes in Shanghai and Guangzhou are due to their higher levels of $\mathrm{NO}_{\mathrm{x}}$ (and hence higher loss rates of $\mathrm{NO}_{2}$ ).
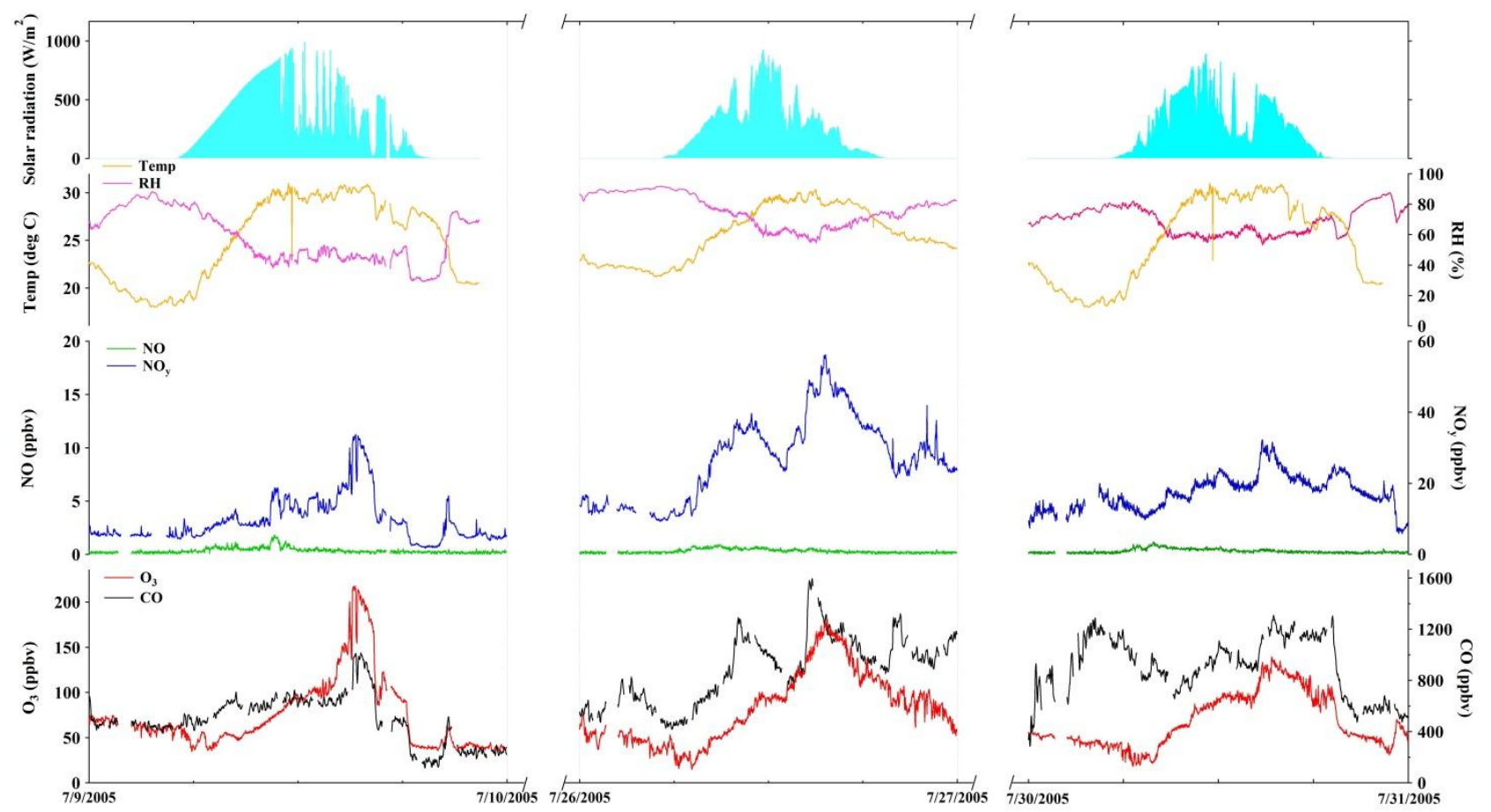

Figure S3. Time series of trace gases and meteorological parameters observed during the selected ozone episode days in Beijing in summer 2005 


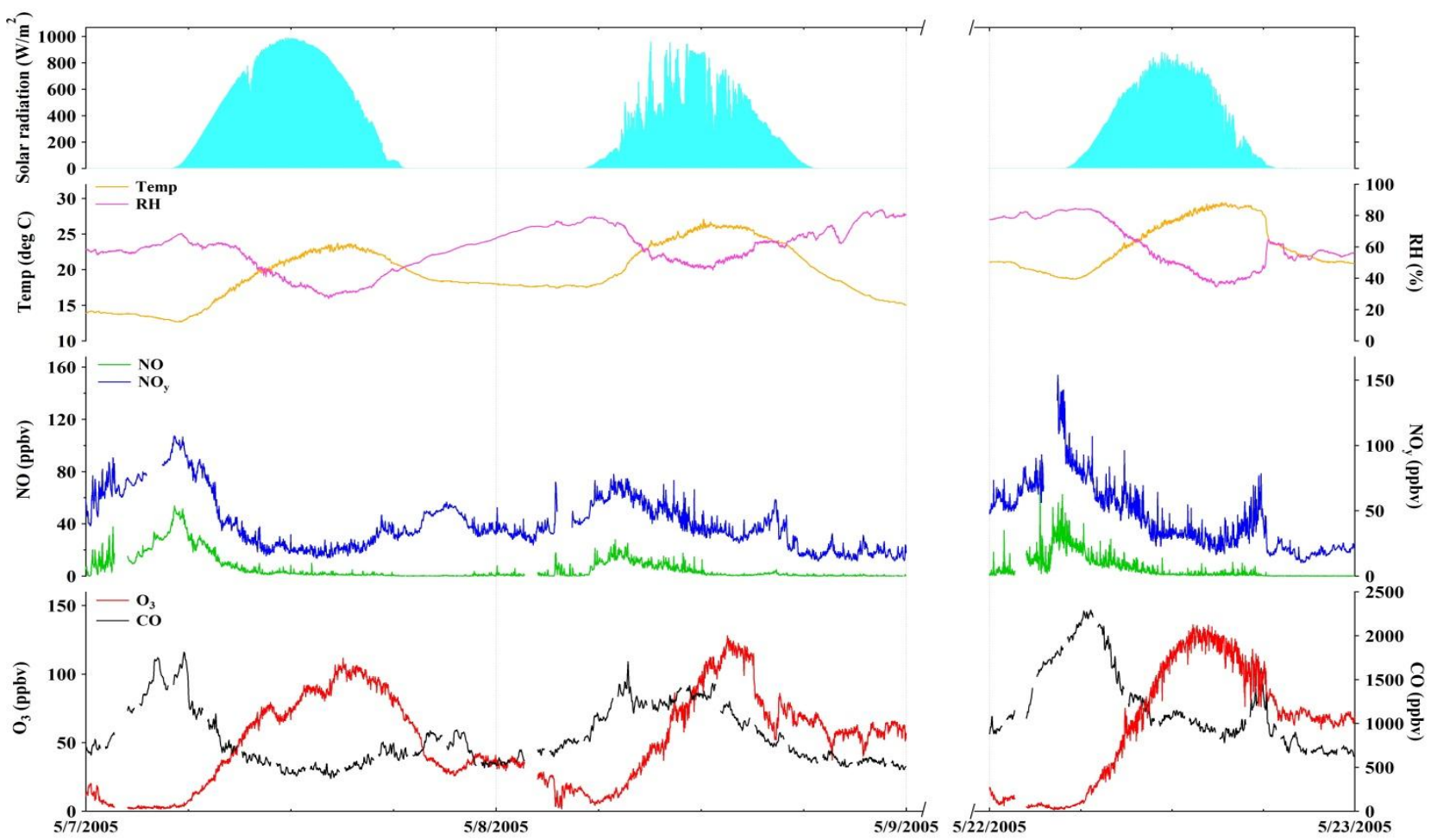

Figure S4. Time series of trace gases and meteorological parameters observed during the selected ozone episode days in Shanghai in late spring/early summer 2005

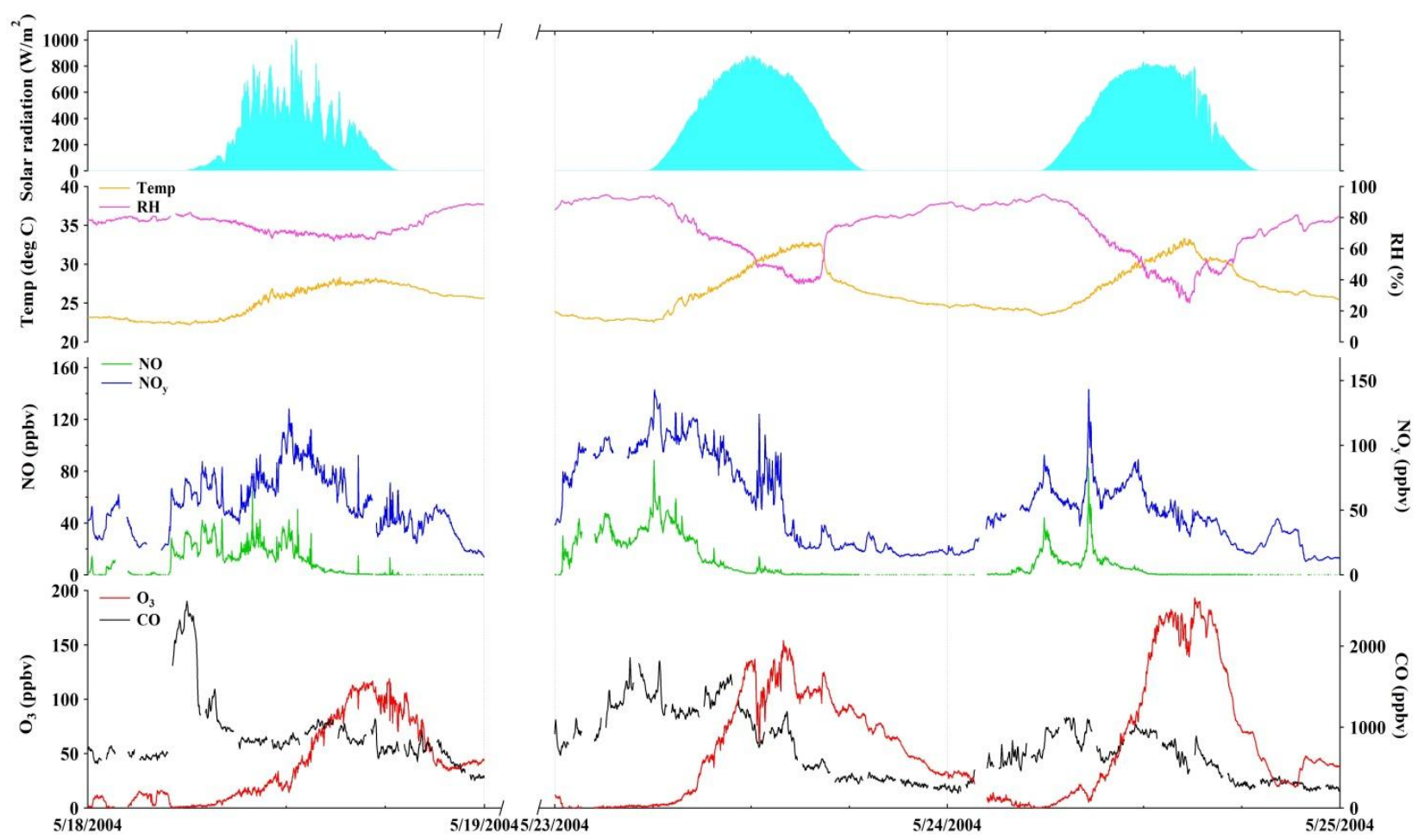

Figure S5. Time series of trace gases and meteorological parameters observed during the selected ozone episode days in Guangzhou in late spring 2004 


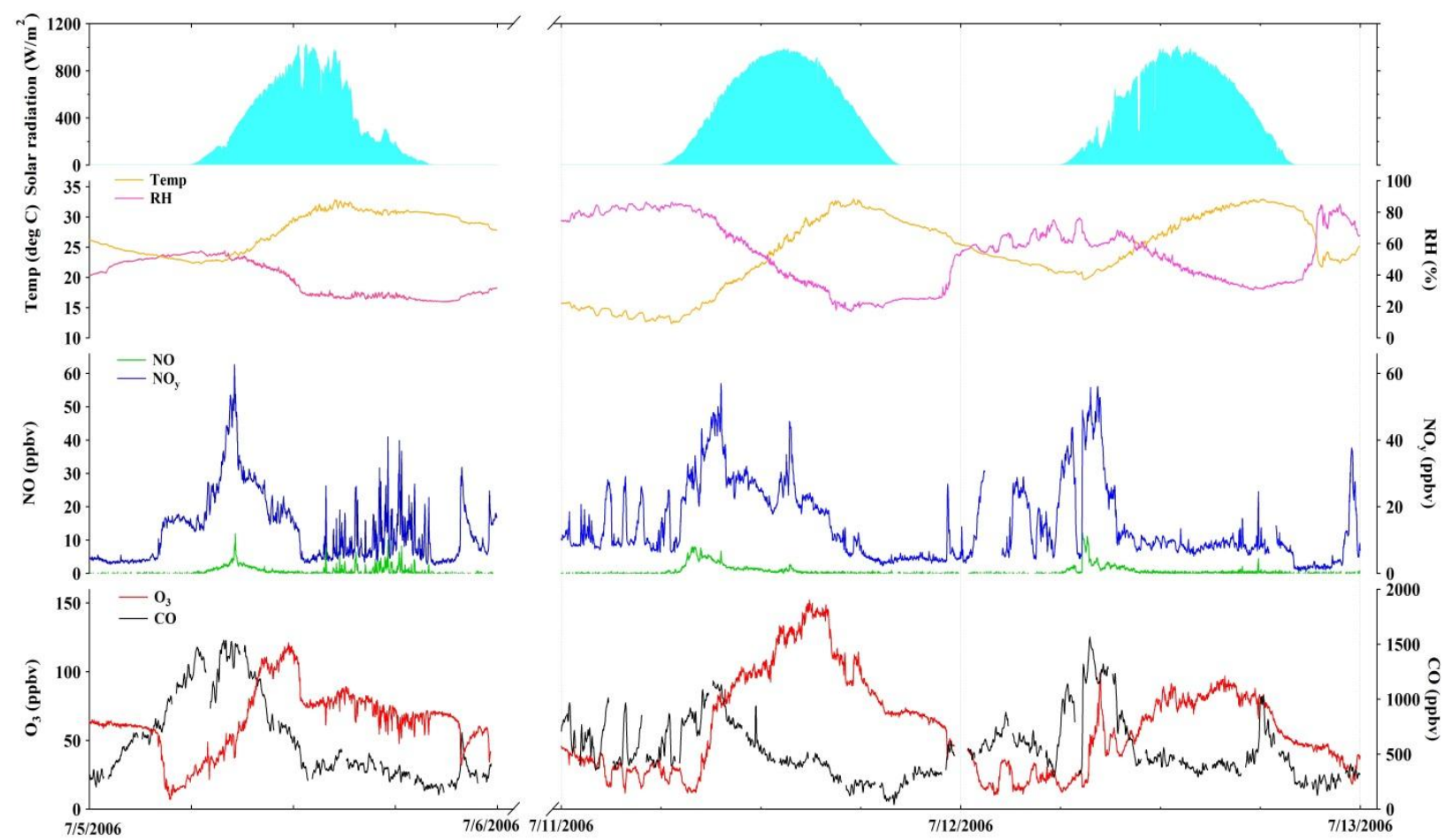

Figure S6. Time series of trace gases and meteorological parameters observed during the selected ozone episode days in Lanzhou in summer 2006

\section{Hydrocarbon reactivity analysis}

Analysis of the hydrocarbon reactivity is critical for understanding the ozone photochemistry at a given location. In the present study, we analyzed the $\mathrm{OH}$ reactivity of major hydrocarbons, which is calculated based on the following equation.

$$
\mathrm{R}_{\mathrm{VOCi}}=\mathrm{k}_{\mathrm{OH}+\mathrm{VOCi}} *\left[\mathrm{VOC}_{\mathrm{i}}\right]
$$

Where, the $k_{O H+V O C}$ is the rate constant of the reaction between a VOC species and $\mathrm{OH}$, and [VOC] is the measured concentration of the VOC species. The rate constants were taken from the Master Chemical Mechanism (v3.2; http://mcm.leeds.ac.uk/MCM/). As the $\mathrm{OH}$ reactivity takes both atmospheric abundances and reactivity towards $\mathrm{OH}$ into account, it is a better proxy than the concentration alone to predict the ozone formation potential of a given species. 